\title{
21303 水中ロボットを用いた基礎力学の教育実践
}

\author{
Educational Practice of Basic Mechanics Using an Underwater Robot
}

\author{
○学 山縣 広和（慶大院） 森田 寿郎（慶大）
}

Hirokazu YAMAGATA, Keio University, 3-14-1 Hiyoshi, Kohoku-ku, Yokohama

Toshio Morita, Keio University, 3-14-1 Hiyoshi, Kohoku-ku, Yokohama

\begin{abstract}
Recently various robot contests have been held to educate future engineers. However, dynamics for the ground based robots are limited due to the size of the contesting robots, making dynamics being left behind at the contest. Thus, robot contests where dynamics have significant influence on solution to the target problem are desired. However, designing such robot contest is difficult on ground level; due to many difficulties like a budget, technical, and/or duration to build large and heavy robot with significant influence of dynamics. The authors have focused on underwater robot contest, because fluid causes large effect in terms of dynamics, even to small robots. We developed new teaching materials of underwater robot for junior high school students and held a workshop on a trial basis. As a result, we found that a large training effect for education of basic dynamics can be obtained by using underwater robot.
\end{abstract}

Key Words: Underwater Robot, Education, ROV, Teaching Effectiveness

\section{1. 緒言}

平成 24 年度から実施された中等教育向けの学習指導要領 では，技術・家庭科において技術の内容が「A.材料と加工に 関する技術」「B.エネルギー変換に関する技術」「C.生物育 成に関する技術」「D.情報に関する技術」の 4 分野となった。 特に分野 D ではプログラムによる計測・制御について, 基本 的な仕組みやプログラム作成等の教育を行うことが義務化 された. そこで, 学習しやすい計測と制御の教材としてロボ ットを用いることが提案され ${ }^{(1)(2)}$, それに伴い工学教育とし て実績あるロボコンの需要も今後高まることが予測される.

しかし, 現在主流である陸上のロボコンは一般的に機体サ イズが小さく, 力学的な影響があまり大きく現れないため, 比較的「作る」という技術的側面に注力した試行錯誤が行わ れる傾向がある( ${ }^{(3)}$.これは親学問である工学的な観点からは 必ずしも理想的であるとは言えない. ゆえに従来と同程度の 作業量を維持しつつ, 重力や推力だけでなく, 浮力や抵抗等 の関係を検討する必要性のある環境でロボコンを行うこと で，工学を意識した教育を行うことが望ましいと考えられる.

そこで本研究では, 重力, 浮力, 力のつり合い等の関係性 を考える必要のある水中ロボット教材を開発し, それを用い て実環境上で発生する事象と概念のすり合わせを行うこと で初歩的な工学知識の定着を試みるワークショップ（以下, WS）を行い, 力学を中心とした工学分野での教育効果につ いて検証を行うこととする.

\section{2. 達成目標の設定}

水中ロボットは, 重力, 浮力, 推力, 流体抵抗等の影響を 受け，その関係性の調整することで動作する. そこで, これ らの中から安定動作に最低限必要な要素を選択して, WS 参 加者 (学習者) の達成目標を「重心, 浮力中心を理解し, 機 体の状況から機体に加わる力を考えられる」とした。

\section{3. 水中ロボット教材の開発}

WS の教材として, 図 1 に示す重心と浮力の調整が可能な 有索式水中ロボット（ROV）を開発した。この水中ロボット は以下のような特徴を持つ.

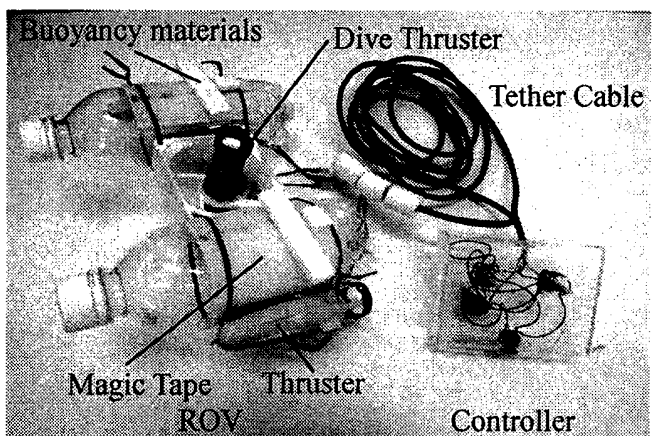

Fig.1 ROV Teaching Materials

- 半田, 穴あけ, 型取り等の複数の加工体験が可能

- 上側面の面テープで浮力材や錘の自在な配置が可能

・面テープでスラスタの位置・角度が調整可能である

- 簡単な回路で, スラスタの推力方向を制御可能

・一台あたりの費用は 3,000 円程度

この特徵を用いた浮力中心, 重心の調整, 推力方向の調整 により, 機体の前後退, 潜航, 旋回の 3 種の動作の相互関係 を調節し, 簡単な回路構成のコントローラで操作できる.

\section{4. ワークショップ}

\section{1 実践概要}

慶應義塾湘南藤沢中等部・高等部の中学 3 年生と 1 年生の 各 3 名の計 6 名を対象に, WS 3 日間で計 10 時間行った. 参加者の内, 3 年生は力のベクトル表現, 浮力, 重力に関し ては既習であり, I 年生はすべての項目について未習である. WS 中は, 常に 2 人以上の指導者が参加者の指導にあたった.

\section{2 授業展開 \\ 4. 2.1 事前アンケート (20 分)}

参加者の水中ロボットへの興味と工学知識の確認するた めに, 事前アンケートを行った. アンケートは水中ロボット や理科, 技術等の興味に関する内容と, 事前知識, 似た力学 系の気球についての自由体図を記述する内容になっている. 
Table.1 Education Effect by the Workshop

\section{2 .2 概要説明（30 分）}

水中ロボットの使用される環境と用いられる技術を説明 した.ここで座標系, 重心, 浮力, 流体抵抗, 力のベクトル 表現, 力のつり合い等について図や実験を用いて説明し, 基 本的な知識を共有した。 また，大会のルールを説明した。

\section{2.3 制作（調整改造とあわせて約 7 時間 30 分）}

参加者の手の届く所に完成品を置き, 実物を用いて説明を 行いつつ作成を行った. その後, 参加者の半分以上が機体を 完成させたことを確認し，調整方法の説明に移行した。

\subsection{4 調整・改造}

機体の重心，浮力中心の位置とスラスタの方向を調整し， 所望の動作を可能にする．調整作業は，参加者と共に機体に 発生した状況を確認しながら行った。この際，状況を自由体 図で表現し，それを用いて考えさせることにより機体の状況 と概念のすり合わせを行わせ，学習内容の定着を目指した。

動作確認後に参加者には各自大会に向けての改造目標を 設定し，それに向けた最適化を行わせた。この間に受ける質 問には，直接回答になるような指導は行わず，状況を明らか にして参加者が自身で考えるような状況を保った。

なお，この時点で大会コースを開放し，練習が可能な状態 にする．全体の状態を見ながら適宜大会に移行した。

\section{2 .5 大会 $(60$ 分程度 $)$}

上下左右に移動し，2つのゲートを通過するコースを用い て大会を行った. 出走回数は最大 2 回で, 往復のタイムを計 測し，良い記録を用いて順位を決定した。

\section{2.6 事後アンケート（20 分程度）}

学習内容の定着を確認するため，興味の変化と自由体図， WS の内容について事前アンケートと比較が可能な内容の設 問を含む事後アンケートを行った。

\section{5. アンケート結果}

5.1 興味の変化に関する評価と考察

水中ロボットや中学校の科目（理科，技術）への興味の強 さに対して事前, 事後アンケートで5段階での回答を求めた. 得られた回答をもとにその平均の変化, 標準偏差の変化, 事 前と事後での有意差とグループごとの平均值の差を標準化 した効果量 (Choen's $d$ ) を算出し，表 1 にまとめた．表 1 の 水中ロボット, 理科, 技術の各項目にある平均值と Cohen's $d$ を確認すると，事前と事後の結果について高い值を維持した 状態で大きな変化は見られない，また，以下に示すアンケー 卜回答から楽しみつつWSに参加したことが確認できる。

Q. 面白かったとろこがあれば教えてください

・ ロボットが 3 次元で動かせること（中 3 ・複数）

・少し違うだけでよくも悪くもなる，思い通りに行 くと面白い（中 1)

Q. 今後水中ロボットで行なってみたいことがありますか

・水中ロボットにカメラを搭載して水中観察（中 3)

・ プール掃除（中 1)

Q. 本 WS で新たに興味を持った部分はありますか （流体の）抵抗の少ない形・粘性の話など（中 3）

以上より，中学生にとって進んだ学習内容に対して, 参加 者が興味を失わずに学習活動を行なったことがわかる.

\section{2 機体最適化行動による概念理解の評価と考察}

参加者は短い時間ながら, 調整自由度を増やす, 重量を増

\begin{tabular}{|c|c|c|c|c|c|c|}
\hline \multirow{2}{*}{ Questionnarie } & \multicolumn{2}{|c|}{ Average } & \multicolumn{2}{|c|}{ Standard Deviation } & \multirow[t]{2}{*}{$t$-value } & \multirow[t]{2}{*}{ Cohen's d } \\
\hline & Prior & Subsequent & Prior & Subsequent & & \\
\hline Underwater robot & 4.50 & 4.50 & 0.76 & 0.76 & 1.000 & 0.000 \\
\hline Science course & 4.67 & 4.67 & 0.47 & 0.75 & 1.000 & 0.000 \\
\hline Technical course & 4.50 & 4.67 & 0.50 & 0.75 & 0.661 & 0.000 \\
\hline Attainment & 0.67 & 5.60 & 0.47 & 1.36 & 0.001 & 1.003 \\
\hline
\end{tabular}

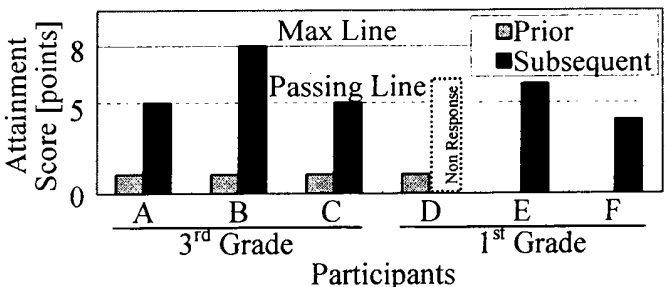

Fig.2 Score Rise of Attainment

加して基本的に沈んだ状態で操作を可能にする, 比重をほぼ 1 にして水中での静止が可能になるようにする等の最適化を 施していた，本研究ではこれらの最適化について，事後アン ケートに記述された改造の説明と自由体図をもとに，その背 景にある根拠から達成度を測定した。本研究では，その達成 度の評価基準として，8 項目のチェックリストを用いた。こ のリストは，(1）から昇順に難易度が上昇し，(5)において,

2 章に挙げた達成目標に到達したものとみなす。

(1) 機体 (課題) の状況を充分に観察できている

（2）機体 (課題) の状況からその背後で発生している力を 想定している

(3) 状況を観察し行うべき最適化を決定できている

(4) 最適化を行うために必要な作業が決定できている

(5) 設定した最適化を行なっている

（6）最適化した状態と記述した自由体図に整合性がある

(7) 自由体図を用いて最適化の意図を説明できている

(8) 設定した目標に対して最適化の内容が妥当である

このチェックリストを用いてアンケートにある自由体図 と改造の説明を点数化し，事前と事後で比較して概念理解と 思考力の向上について調査した. チェックリストの到達段階 を点数として評価した結果を図 2 に示す. 全参加者の中で達 成目標（5 点）に到達した参加者は 4 名であった。また，表 1 の達成度の項目によれば得られた有意差が 0.001 , Cohen's $d$ が 1 を上回ることから，WS 前後の達成度には有意な変化が 認められ，大きな効果が得られたことがわかる。一方で, 機 体の最適化と自由体図の整合性を取り，他者に説明できた 6 点以上の参加者は 2 名であった。この点について，6点末満 の参加者の回答した改良の説明を確認したところ, その理解 度と表現力にばらつきが認められるものの，根拠を持った最 適化までは参加者全員が到達した。これより，5.1 節の内容 と合わせて, 本 WS は興味を低下させることなく高い教育効 果が得られる教育手法であると考えられる.

\section{6. 結言}

今回提案した WS の結果からは, 水中ロボットを用いた工 学教育は参加者に興味を失わせることなく, 初歩的な力学を 意識, 理解させることに効果があることが示唆された。今後 は得られた知見を生かして内容を改良しつつ，引き続きWS を行いその効果の検証を行う。

\section{参考文献}

(1) 古平 真一郎ら，自律型ロボット教材を用いた「プロ グラムによる計测・制卸」学習の授業実践に基づく学 習効果の検証，日本産業技術教育学会誌 51(2009).

(2) 西ヶ谷浩史ら, 自律型 3 モー夕制御ロボット教材を 用いた計測の授業, 情報好理学会研究報告コンピュー 夕と教育研究会報告 2009(15)

（3）堤 博貴ら，競技用小型ロボット制作実習における創 造的教育の試み, 日本機械学会関東支部総会講演会講 演論文集 2009(15). 